Federal Reserve Bank of Dallas

Globalization and Monetary Policy Institute

Working Paper No. 283

http://www.dallasfed.org/assets/documents/institute/wpapers/2016/0283.pdf

\title{
Central Bank Communications: A Case Study*
}

\author{
J. Scott Davis \\ Federal Reserve Bank of Dallas \\ Mark A. Wynne \\ Federal Reserve Bank of Dallas
}

September 2016

\begin{abstract}
Over the past twenty five years, central bank communications have undergone a major revolution. Central banks that previously shrouded themselves in mystery now embrace social media to get their message out to the widest audience. The Federal Reserve System has not always been at the forefront of these changes, but the volume of information about monetary policy that the Federal Open Market Committee (FOMC) now releases dwarfs what it was releasing a quarter century ago. In this paper we focus on just one channel of FOMC communications, the post-meeting statement. We document how it has evolved over time, and in particular the extent to which it has become more detailed, but also more difficult to understand. We then use a VAR with daily financial market data to estimate a daily time series of U.S. monetary policy shocks. We show how these shocks on Fed statement release days have gotten larger as the statement has gotten longer and more detailed, and we show that the length and complexity of the statement has a direct effect on the size of the monetary policy shock following a Fed decision.
\end{abstract}

JEL codes: E58, E65

\footnotetext{
* J. Scott Davis, Federal Reserve Bank of Dallas, Research Department, 2200 N. Pearl Street, Dallas, TX 75201. 214-922-5124. Scott.davis@dal.frb.org. Mark A. Wynne, Federal Reserve Bank of Dallas, Research Department, 2200 N. Pearl Street, Dallas, TX 75201. 214-922-5159. Mark.a.wynne@dal.frb.org. We thank the editors and anonymous referees for helpful comments on the previous draft. We also thank Valerie Grossman, Adrienne Mack and Kelvin Virdi for research assistance with this project at various stages and Christopher Koch and María Teresa Martínez-García for helpful conversations. The views in this paper are those of the authors and do not necessarily reflect the views of the Federal Reserve Bank of Dallas or the Federal Reserve System.
} 


\section{[1] Introduction}

In 1981, Karl Brunner wrote that "Central Banking ...thrives on a pervasive impression that [it] ...is an esoteric art. Access to this art and its proper execution is confined to the initiated elite. The esoteric nature of the art is moreover revealed by an inherent impossibility to articulate its insights in explicit and intelligible words and sentences." (Brunner, 1981, cited in Goodfriend (1986)). It is probably fair to say that this view characterized the conventional wisdom within

the Federal Reserve System and most other central banks well into the 1980s. But over the past two decades there have been major changes in central bank communications with financial markets and the general public. The Federal Reserve System has not always been a leader in adopting new communications practices, but since the onset of the global financial crisis of 2007-2008, and especially since conventional interest rate policy ran up against the zero lower bound in December 2008, communications about monetary policy have taken on an added importance.

This paper focuses on just one aspect of Federal Reserve communications about monetary policy, namely the post-meeting statement released by the Federal Open Market Committee (FOMC) after each meeting. We document how this statement has evolved under the chairmanships of Alan Greenspan and Ben Bernanke. It was not until 1994 that the FOMC released a statement immediately after a policy meeting. Prior to 1994, analysts and the general public had to wait until after the subsequent meeting of the FOMC to know what the policy directive was. Originally statements were only issued when policy (as measured by the level of the federal funds rate) changed. Since 1999, the FOMC has issued a statement after every scheduled meeting, regardless of whether the stance of policy has changed. We will show how the statement has grown longer and more detailed over time, especially after the federal funds rate was lowered to its effective lower bound in December 2008, where it remained until December 2015. We contrast the evolution of the FOMC's post-meeting statement with the evolution of the press release that the Bank of Canada started issuing in 1997 to announce changes in policy. The trend towards longer statements is less pronounced is the case of Canada. We also show that the Bank of Canada's policy statements are easier to understand, 
and speculate that this may be because the Bank of Canada spent less time at the effective lower bound for its main policy rate than the FOMC and thus engaged in less in the way of unconventional monetary policy.

We then go on to show how as the FOMC's policy statement has gotten longer and more complex, its impact has increased. We estimate a daily series of U.S. monetary policy shocks using daily financial market data and a VAR with sign-restrictions. With this we can identify the monetary policy shock on the day that a statement was released. We show how the absolute size of these monetary policy shocks on statement days has increased in the zero lower bound period, as the length and information content of the statement has increased. Furthermore, we show that after controlling for the actual policy change announced in the statement, the length and complexity of the statement has an effect on the financial market impact of a given Fed policy change. Thus over time as Fed statements have gotten longer and more complex, their market-moving impact has increased.

Thus this article will chart the evolution of the post-meeting Fed statement from the first one issued in 1994 to the end of Ben Bernanke's tenure as Chairman. As noted above the statements have gotten longer and more complex over time as the amount of information contained in the statement has increased and the FOMC wrestled with unconventional monetary policy in the form of large scale asset purchases and forward guidance. Originally the statement contained just a vague description of Fed policy actions, but now it contains an assessment of the Fed's outlook for the economy, balance of risks, and a forecast, if not an outright commitment on future policy actions. Thus over the last 20 years, and especially during the zero lower bound period, the Fed has begun to use the post-meeting statement itself as a instrument with which it can influence and move markets.

\section{[2] Background}

There is a rich literature on the economic theory of why central banks should be more transparent and communicate with financial markets and the general public. One of the seminal articles was Goodfriend (1986) which critically evaluated some of the arguments in defense of secrecy in the conduct of monetary policy put forward by the Federal Reserve in 
response to a Freedom of Information Act suit in 1975. Goodfriend concluded that there were indeed conditions under which central bank secrecy might be desirable, but that the theoretical arguments in defense of secrecy were at best inconclusive. When considered in conjunction with the presumption that government secrecy was an anathema to the healthy functioning of democracy, Goodfriend argued that “...further work is required to demonstrate that central bank secrecy is socially optimal."(Goodfriend, 1986, 90) By the 1990s, inflation targeting was becoming a popular framework for the conduct of monetary policy, and Bernanke, Laubach, Mishkin and Posen (1999) highlighted the importance of communication as part of an inflation targeting strategy. Guthrie and Wright (2000) argued that in the case of the Reserve Bank of New Zealand - which had pioneered the use of an inflation targeting strategy in 1990 - its credibility was such that by simply communicating where it wished short-term interest rates to be it could elicit a market response without actually undertaking any open market operations to back up its words. Blinder et al. (2001) reviewed existing practice on central bank communications around the turn of the century. They take as their point of departure the principle that when it comes to central banking communication "...full transparency ought to be the presumption, with a few conspicuous exceptions" (Blinder et al., 2001, xvii), with the case for transparency resting on arguments for democratic accountability and policy effectiveness. They review the communications practices of a number of central banks, focusing on such things as the post-meeting statement, publication of meeting minutes and transcripts, publication of forecasts, and so on. Amato, Morris and Shin (2002) showed that it is possible for a central bank to be too transparent, especially when public information serves the dual role of conveying fundamental information as well as serving as a focal point for better coordination, and reminding us that the optimal amount of transparency (to the extent that it can be quantified) is somewhere between zero and 100 percent. $^{2}$ Friedman (2003) critically reviews the language used by advocates of inflation targeting, and argues that "By forcing participants in the monetary policy debate to conduct the discussion in a vocabulary pertaining solely to inflation, inflation targeting fosters over time the atrophication of concerns for real outcomes." (Friedman, 2003, 122) He sees this as yet another example of the familiar principle that “...the

\footnotetext{
${ }^{2}$ A similar point is made by Dale, Orphanides and Österholm (2011), who argue that central banks should limit themselves to communicating the information it knows most about.
} 
language in which ...debate takes place exerts a powerful influence of the substance of what participants say, and eventually even over what they think." (Friedman, 2003, 114) Blinder et al. (2008) surveyed the by-then large literature on central bank communication. Noting the wide variation on communication practices across the world's central banks they concluded that “...a consensus has yet to emerge on what constitutes an optimal communication strategy" (Blinder et al., 2008, 910).

Ehrmann and Fratzscher $(2005,2007,2013)$ seek to quantify various aspects of how central banks communicate. They have examined communications via speeches by policy committee members and post-meeting press conferences and document how certain features of such communications - such as the extent to which committee members agree on the economic outlook in their speeches, or provide similar outlooks for monetary policy - affect the predictability of monetary policy decisions. Berger, Ehrmann and Fratzscher (2011) examine how communications by the ECB are filtered through the media, and document how various factors, such as the inflation environment or the extent to which a decision is unanticipated, impacts the tone of media coverage. Finally, Myatt and Wallace (2014) show that under certain circumstances a central bank may choose to limit the clarity of its communications with the general public so as to better achieve an output stabilization objective.

This paper approaches the question of central bank communication from a somewhat different angle. Our interest is in attempting to quantify the information content in the texts of one specific communication tool - specifically, the post-meeting statement - used by the FOMC to explain its thinking to the general public. There is a small literature that has attempted similar exercises in the past. Seminal work done at the Federal Reserve Bank of Dallas many years ago attempted to evaluate the information content of the Beige Book that is published by the Federal Reserve System about two weeks prior to each FOMC meeting. Balke and Petersen (2002) quantified the qualitative information in each Beige Book by assigning numerical scores to comments about developments in real activity and inflation and examined the ability of the Beige books to predict real economic activity. They coded the qualitative information by reading each Beige Book and assigning scores ranging from -2 to 2 to various words and 
phrases. For example, text describing "moderate" or "normal" economic growth was typically scored a 0.5 , while text describing "strong" economic activity might rate a score of 1.0 or 1.5. Armesto, Hernández-Murillo, Owyang and Piger (2009) built on that work by using software developed by linguists to automate the quantification of the qualitative information in the Beige books, specifically to generate "...systematic measures of the levels of optimism and pessimism contained in the narrative of the Beige Book" (Armesto, Hernández-Murillo, Owyang and Piger, 2009, 41.) They essentially confirmed the earlier findings of Balke and Petersen using more sophisticated econometric techniques. Fulmer (2013) performs a similar exercise using slightly different linguistic software (the Stanford Parser) and reaches similar conclusions (the Beige Book has some predictive power for future economic activity but is best suited as a proxy for current quarter economic activity.) And finally Bligh and Hess (2007) examined how the language in Fed Chairman Alan Greenspan's speeches and testimonies evolved in response to changing economic conditions using computerized content analysis (specifically, the Diction 5.0 program of Hart (2000) that is also used by Armesto, Hernández-Murillo, Owyang and Piger (2009)).

\section{[3] The Post Meeting Statement}

FOMC communications come in many forms, from the post-meeting statement, to meeting minutes and transcripts, post-meeting press conferences, the survey of economic projections, congressional testimony by the Chair, speeches and interviews by the various Reserve Bank presidents and members of the Board of Governors. In this paper we will focus on just the postmeeting statement. As noted in the introduction, it was not until February 1994 that the FOMC started issuing a statement after each regularly scheduled FOMC meeting. The first statement was just 99 words long, in marked contrast to what was to come later. There was no reference to a specific level of interest rates, to specific indicators of economic activity or to where policy might be headed in the future. A specific value for the federal funds rate was not mentioned in the initial statements. Rather the language was cast in terms of pressure on reserve positions or in terms of seeing increases in the discount rate fully reflected in interest rates in the federal funds market. In February 1995 the Committee announced that all changes in the stance of 
monetary policy would be announced after the meeting. It was not until July 1995, when the Committee had shifted to easing the stance of monetary policy that mention was made of a specific level of the federal funds rate, when an a decision to ease monetary policy was expected to "...be reflected in a 25 basis point decline in the federal funds rate from about 6 percent to about 5 3/4 percent." Through 1996, 1997 and 1998 the FOMC referred to target levels for the funds rate of "around" or "about" a particular value and only issued statements following decisions to change the funds rate. Starting with the May 1999 meeting, the FOMC announced that it had made no change in policy, and initiated the practice of releasing a statement after every meeting regardless of whether the stance of policy had changed. Starting in June 1999, it began to refer to specific "target" levels for the funds rate. Also starting in 1999 the Committee began to issue forward guidance of a sort in the form of an assessment of the perceived risks going forward.

By 2003 the Committee was worried about inflation getting too low, and lowered the federal funds rate to the then-unprecedented level of 1 percent. Starting with the August 2003 meeting the Committee again began issuing forward guidance about the stance of policy, noting that it believed that "...policy accommodation can be maintained for a considerable period." In January 2004, the Committee changed this language to state that it believed that it could "...be patient in removing its policy accommodation." In May 2004 it altered the language once again to state that "...policy accommodation can be removed at a pace that is likely to be measured" and then raised the federal funds rate by 25 basis points at its June meeting. The Committee raised the funds rate by 25 basis points at each of the subsequent sixteen meetings. In response to deteriorating economic conditions as a result of the financial crisis, on December 162008 the FOMC lowered the target for the federal funds rate to a range of 0 to $1 / 4$ percent, and noted that "...weak economic conditions are likely to warrant exceptionally low levels of the federal funds rate for some time". This language was subsequently altered to read "...exceptionally low levels of the federal funds rate for an extended period". Thus began the period of unconventional monetary policy. 
The expectation that the fed funds rate would remain at an exceptionally low level for an extended period was included in every statement through August 2011, when the language was altered to “...at least through mid-2013." By January 2012, this was changed to "at least through late 2014", and by September it had been pushed back to "at least through mid-2015." But at the December 2012 meeting, the Committee made a radical change in how it communicated its intentions. The Committee adopted language stating that it anticipates that “...this exceptionally low range for the federal funds rate will be appropriate at least as long as the unemployment rate remains above $6 \frac{1}{2}$ percent, inflation between one and two years ahead is projected to be no more than a half-percentage point above the Committee's 2 percent longer-run goal, and longer-term inflation expectations continue to be well anchored." Thus, over the course of two decades, the Committee has gone from vague language about "pressure on reserve positions" to concrete statements about its target range for the federal funds rate and the specific economic developments that will prompt a change in that target in the future.

\section{[4] Text analysis}

For this project we examined the texts of the 131 post FOMC meeting statements issued by the FOMC under Chairmen Greenspan and Bernanke. Figure 1 plots the evolution of the length of the post-meeting statement (as measured by the number of words in the statement) under Chairmen Greenspan and Bernanke. The red vertical line in the figure marks the end of Alan Greenspan's term as Chairman in January 2006, and the transition to Ben Bernanke's term as Chairman. The grey shaded area denotes the zero lower bound (ZLB) period that began in December 2008 and lasted through the end of Ben Bernanke's term as Chairman in January 2014.

As noted above, the statement issued on February 4, 1994 was just 100 words long. The statement issued on January 29, 2014 was 841 words long, only slightly more concise than the record 878 words in the statement released on December 18, 2013. Figure 1 shows a clear trend towards wordier statements, with the trend intensifying not with the change of chairman 
in 2006 but rather when the FOMC ran up against the zero lower bound (ZLB) on interest rates in December 2008 when it lowered the target level of the federal funds rate to the 0 to 25 basis point range, where it stayed until December 2015. For the period from December 2008 through the end of Chairman Bernanke's tenure in January 2014, the FOMC has relied on unconventional monetary policy - specifically, large scale asset purchases and forward guidance - to support economic activity.

There are a number of different approaches to assessing the ease of understanding a text. The (relatively) well known Flesch-Kincaid indexes (see Flesch (1948) and Kincaid et al. (1975)) were developed to quantify the difficulty of understanding a text written in contemporary English. The Flesch reading ease score is based on the number of syllables, words and sentences in a text. The higher the score (which typically falls in a range of 0 to 100), the greater the reading ease. The Flesch-Kincaid Grade Level Formula simply translates the Flesch score into a U.S. grade level equivalent. $^{3}$

The grade level equivalent measure of each FOMC statement through Greenspan and Bernanke's tenure's is presented in Figure 2. Again, the red vertical line in the figure represent the transition from Greenspan to Bernanke in 2006 and the shaded grey area the ZLB era that began in 2008 .

There was considerable variation in the grade level of the statements during the Greenspan Fed, with some statements at the reading level of a college sophomore and some at the level of a Ph.D. student. ${ }^{4}$ Statements from the Bernanke Fed started at the level of a college sophomore or junior, but starting with the financial crisis and then when the Fed hit the ZLB, there was a sharp and nearly monotonic increase in the grade level of the statement. The grade level equivalent measure topped out at 21, the level of a $5^{\text {th }}$ year Ph.D. student, in September 2013 (where the Fed surprised markets by not starting to taper the quantitative easing program).

\footnotetext{
${ }^{3}$ One caveat to keep in mind when looking at the Flesch-Kincaid grade level score is that ideally a text should have at least 200 words before this scoring can be used (see Graesser et al., 2004, 7).

${ }^{4}$ Assuming that the Flesch-Kincaid grade levels 13 through 16 correspond to college level comprehension, and grade levels 17 and above correspond to postgraduate level.
} 
Table 1 reports the average word length and grade level equivalent measure of the statement during various subperiods. As in the figures, we distinguish between the statements issued under Chairman Greenspan and Chairman Bernanke. We distinguish between the statements issued under Chairman Greenspan before May 1999, and those issued after May 1999. Recall that it was at the May 1999 meeting that the FOMC decided to issue a statement after every meeting regardless of whether the stance of policy had changed or not, and in 1999 the Fed began including their assessment of the balance of risks in the statement. We also distinguish between the statements issued under Chairman Bernanke in the period before the FOMC ran up against the ZLB and the period since (i.e. since December 2008) when it has been engaged in unconventional monetary policy. The average statement has gone from 120 words long in the pre-1999 era to 530 words long in the ZLB era. In addition, the grade level equivalent measure shows that the statement has advanced from the reading level of an upper level undergraduate before the ZLB period to a master's degree student after the ZLB was reached.

Table 2 reports some simple tests for differences of means to show that the differences are statistically significant. The cells above the diagonal report the mean difference in word length of the post-meeting statement between the period indicated in the column and that indicated in the row. The tests show that most differences in word count and grade level measures across the subperiods are statistically significant. This is especially true for the statements in the ZLB period, which are clearly longer and far more technical and complex than Fed statements in the pre-ZLB period. ${ }^{5}$

In short, the Fed statements are getting longer and more complex. As we will now argue, this is a sign that the Fed statement contains more information. The evolution of the Fed statement over the last 20 years shows that the statement has gone from a vague description of past Fed policy actions to a clear description of the Fed's outlook for the economy and a forecast, if not

\footnotetext{
${ }^{5}$ Based on the trend towards ever longer statements apparent in Figure 1, especially in the last full year of Chairman Bernanke's tenure, one might well question the validity of tests for differences of means in the word counts. The pattern in Figure 1 shows a step up in the average length of the post meeting statement after the FOMC started engaging in unconventional monetary policy in December 2008, remaining fairly stable in the 400 to 500 word range, with the word length becoming a bit unanchored over the course of 2013. The issue of potential non-stationarity is not as apparent in the index of Flesch-Kincaid readability, although some of the statements issued towards the end of Chairman Bernanke's tenure score at a $20^{\text {th }}$ grade readability level.
} 
an outright commitment, to future policy actions. In the next section we will show how this trend towards releasing more information in the statement is associated with greater financial market responses on the day that the statement is released.

\section{[5] An international perspective}

Before proceeding to the detailed econometric analysis, it is worth pausing to get some comparative perspective of the characteristics of monetary policy statements. Each central bank has its own unique way of formulating and communicating monetary policy decisions. Mandates and decision making processes differ across central banks, as do the means of communicating decisions. We decided to look at the recent record of one other central bank in the English speaking world - the Bank of Canada - to see how its policy statement (or rather the press release announcing its policy decisions) has evolved over the past two and a half decades.

The Bank of Canada starting issuing press release announcing monetary policy decisions in June 1997. The first statement was 128 words long and had a Flesch-Kincaid grade level readability of 12.4. The first press release was issued at the beginning of a policy tightening cycle (as was the case with the first post-meeting statement by the FOMC. Figure 3 shows how the word count of the press release has evolved over time through the end of $2015 .^{6}$ The figure also include three vertical reference lines demarcating the tenures of the four governors of the Bank of Canada over this period, as well as shading demarcating the Bank of Canada's experience at the zero lower bound. We date that episode as beginning in April 2009, when the target rate for the overnight rate was lowered to $1 / 4$ per cent which the Bank judged to be the effective lower bound for that rate. The overnight rate was maintained at $1 / 4$ percent until June 2010, when it was raised to $1 / 2$ percent. The tightening cycle that began in June 2010 lasted until September 2010, by which time the rate had been raised to 1 percent, where it remained until

\footnotetext{
${ }^{6}$ Note that there were two press releases issued in October 2008 , one on October 8,2008 , the second on October 21 , 2008. The October 8,2008 press release was issued as part of the coordinated action by the Federal Reserve, the European Central Bank, the Bank of England, the Swiss National Bank and Sveriges Riksbank to stabilize economic activity in the wake of the Lehman failure. The bank of Canada cut its policy rate by $1 / 2$ percentage point at that time. On October 21, 2008 the Bank of Canada announced that it was cutting its policy rate by a further $1 / 4$ percentage point to $2 \frac{1}{4}$ percent. Figure 3 just shows the word count for the October 8 press release.
} 
January 2015, when it was lowered to $3 / 4$ percent in response to the sharp drop in oil prices. Subsequent policy action took the rate to $1 / 2$ percent where it remained through the end of 2015.

Note that as with the FOMC, the Bank of Canada initially only issued a press release when it changed the stance of monetary policy. The first press release announcing no change in monetary policy was issued in December 2000. Note also that prior to 2000 the timing of policy decisions and announcements was not set in advance. In September 2000 the Bank of Canada announced that it would make policy decisions and announcements eight times a year on a prespecified schedule, similar to that followed by the FOMC.

Comparing the patterns in Figure 3 with that in Figure 1, we see a general tendency towards longer policy statements (as with the FOMC), but the tendency is not as pronounced. The longest statement in our sample was 717 words long and issued in October 2011. The longest statement issued by the FOMC was the 878-word long statement issued in December 2013. Note also that the statements are not notably longer during the period when the Bank of Canada was up against the effective lower bound on its policy rate. This period lasted only from April 2009 through June 2010. At the time the Bank lowered its policy rate to its effective lower bound, it also adopted (date-based) forward guidance, noting that "Conditional on the outlook for inflation, the target overnight rate can be expected to remain at its current level until the end of the second quarter of 2010 in order to achieve the inflation target." This language was included in seven subsequent press releases (through the March 2010 release), and was not included in the April 2010 release. In June 2010, the Bank raised its policy rate to $1 / 2$ percent.

Unlike the Fed, the Bank of Canada never engaged in quantitative easing when it hit the effective lower bound on its policy rate, relying exclusively on forward guidance to provide additional stimulus. ${ }^{7}$ Also, the Bank of Canada was up against the effective lower bound on its policy rate for a much shorter period of time than was the Fed.

\footnotetext{
${ }^{7}$ The Bank of Canada's experience with unconventional monetary policy is reviewed in Poloz (2015). The Bank of Canada's balance sheet did expand between October 2008 and June 2010 for other reasons.
} 
Of perhaps greater interest is the fact that the Bank of Canada's policy statement did not seem to become more complex over time even as it engaged in unconventional monetary policy. The Flesch-Kincaid grade level readability of the text of the policy press release is shown in Figure 4 and averaged 14.6 over the sample shown (with a standard deviation of 1.2 grade levels), about the equivalent of a college junior. Contrast this with the pattern shown in Figure 2 where the Flesch-Kincaid readability of the post-meeting FOMC statement exceeded 20 by 2013.

Tables 3 and 4 provide some simple statistics on average word count and grade-level readability under the four governors who ran the Bank of Canada during our sample period. In addition to providing statistics on Mark Carney's full term as governor, we also distinguish between the periods during his governorship when the Bank was up against the effective lower bound on its policy rate. Two thing stand out from Table 4. First, the most statistically significant changes in the grade-level readability of the statement occurred under Governor Poloz: the readability of the policy press release is more than one grade level lower (i.e. more readable) during his tenure than under the tenure of his three predecessors. Second, the most statistically significant changes in the word count occur between the governorships of Gordon Thiessen and David Dodge and their successors.

\section{[6] Textual complexity and monetary policy shocks}

While textual analysis of the FOMC post-meeting statements is interesting, it is worth going further to see how these textual differences might matter (if at all) for how financial markets respond to the statement. Using daily financial market data it is possible to estimate a daily time-series of monetary policy shocks. With this we can identify the shock on the exact day that a statement was released, and thus isolate the market-moving impact of the statement.

To estimate these shocks we use a VAR estimated with daily financial market data and identified with sign restrictions, as in Antolín-Díaz and Rubio-Ramírez (2015). We include 5 variables of daily financial market data in the VAR: the 10-year TIPS interest rate (R), 10-year inflation expectations ( $\pi^{e}$, measured as the difference between the 10-year nominal rate and the 10-year TIPS rate), the nominal effective exchange rate (FX), the value of the S\&P 500 (SP) and the VIX (VIX). For the first 2 variables, the observation will be the daily percentage point 
change, for the other 3 the observation is the daily percentage change. We use the VAR to identify the following 4 shocks: a monetary shock (M), a risk shock $(\sigma)$, a demand shock (D), and a supply shock (Sup).

To estimate this VAR and identify these 4 shocks using the method of sign restrictions, begin by estimating a reduced form $\operatorname{VAR}(1)$ using the 5 financial market variables:

$X_{t}=A X_{t-1}+u_{t}$

Where $X_{t}$ is a five by one vector with the 5 variables in the estimation and $u_{t}$ is the vector of reduced form residuals. Then we identify the impact matrix $S$ where $u_{t}=S e_{t}$, where the vector $e_{t}$ is a five by one vector, the four exogenous shocks and one measurement error. ${ }^{8}$

The impact matrix is the matrix $S$ where $S S^{\prime}=u u^{\prime}$, the covariance matrix of the reduced form residuals. If we were identifying shocks through a set of ordering restrictions, we would assume that $S$ is a lower triangular matrix and is thus the output of a Cholesky decomposition of the covariance matrix. Since the data is daily financial market data, such an ordering restriction would be inappropriate, so we instead assume that $S$ has certain sign restrictions.

The sign restrictions that identify these 4 shocks (and one measurement error) are reported in the top half of Table 5. Our identification strategy assumes that on the day of the shock, a monetary shock leads to an increase in the real interest rate, a decrease in expected inflation, U.S. dollar appreciation, and a decline in the S\&P 500. A risk shock leads to a fall in the real interest rate (through a risk-induced flight to safety into U.S. treasuries), an appreciation of the dollar (through the same flight to safety), a fall in the S\&P 500, and an increase in the VIX. An aggregate demand shock leads to an increase in the real interest rate, an increase in expected inflation, and dollar appreciation. An aggregate supply shock leads to an increase in the real interest rate, a fall in expected inflation, dollar appreciation, and an increase in the S\&P 500.

We run a random search to identify the possible $S$ matrices that both satisfy these sign restrictions and the criteria that $S S^{\prime}=u u^{\prime} .{ }^{9}$ There are many possible candidate matrices that

\footnotetext{
${ }^{8}$ Identification of shocks requires the matrix $S$ to be invertible and thus square.
} 
satisfy both these criteria. For our purposes we will identify and calculate results from 1000 possible $S$ matrices. The average impact matrix, after averaging over these 1000 possible $S$ matrices, is presented in the bottom half of table 5 . This is the effect of each one of the four shocks in the model on the daily change in the 5 financial market variables. We estimate that a one standard deviation contractionary monetary policy shock, $M=1$, leads to a 1.9p.p. increase in the real interest rate, a 1.5p.p. decrease in the expected inflation rate, a 0.1 percent increase in the nominal effective exchange rate, a 0.63 percent decline in the S\&P 500, and a 2.3 percent increase in the VIX.

\section{[6.1] Backing out a sequence of shocks}

After finding a possible candidate for this matrix $S$, call it $S_{i}$, it is possible to back out these shocks from the reduced form residuals $u_{t}$. Since $u_{t}=S_{i} e_{i, t}$ and $S$ is invertible, then $e_{i, t}=S_{i}^{-1} u_{t}$. A separate sequence of shocks, $e_{i, t}$, is associated with each possible matrix $S_{i}$. Since we calculate 1000 possible $S_{i}$ matrices and thus 1000 possible shock sequences $e_{i, t}$, a simple average can be taken across these 1000 possible sequences. The average shock sequence for each of our four shocks is plotted in Figure 5.

From these time series graphs of the 4 shocks in the model, it appears that other than a spike during the acute part of the crisis, the magnitudes of the demand and supply shocks are fairly constant between the pre- and post-ZLB periods. The same is not true however for the monetary shocks and the risk shocks, which appear to have higher magnitude in the post-ZLB period than in the pre-Lehman period.

We can calculate the variance of each of the four shocks in the pre-Lehman and post-ZLB periods. ${ }^{10}$ By definition the variance of each shock over the entire sample is equal to one. This simply arises from the fact that the shocks are identified with $u_{t}=S e_{t}$ and the identification

\footnotetext{
${ }^{9}$ Identify the lower triangular matrix $C$ where $C$ is a Cholesky decomposition of $u u^{\prime}$. Next, denote $X$ as a square matrix (the same size as $C$ ) of random elements. Perform a QR decomposition of $X$ where $Q Q^{\prime}=I$ and $R$ is an upper triangular matrix. The trial $S$ matrix is $\hat{S}=C Q$. If $\hat{S}$ satisfies the sign restrictions, keep $\hat{S}$, if not, discard and estimate a new random matrix $X$. Stop the process after finding 1000 potential matrices $\hat{S}$ that satisfy the sign restrictions.

${ }^{10}$ The pre-Lehman period is from the start of the sample in January 1999 to September 12,2008 . The post ZLB period is from December 17, 2008 to the end of the sample in November 2015.
} 
matrix must satisfy $S S^{\prime}=u u^{\prime}$, so the covariance matrix of the vector of shocks, $e e^{\prime}$, is simply the identity matrix. But the variance of the estimated shocks within the two subsamples is reported in Table 6. The table shows that the variances of the supply and demand shocks are roughly the same across the two subperiods, but there is a statistically significant increase in the variance of the risk and monetary shocks in the post-ZLB period. ${ }^{11}$

Since these monetary shocks are measured with daily data, it is possible to connect this increased variance to specific Fed actions. To do this, we begin by connecting these daily monetary shocks to specific Fed meetings and statements.

It is interesting to note that in the statement from May 1999, the first meeting when a statement was released without a policy change, says:

\begin{abstract}
"While the FOMC did not take action today to alter the stance of monetary policy, the Committee was concerned about the potential for a buildup of inflationary imbalances that could undermine the favorable performance of the economy and therefore adopted a directive that is tilted toward the possibility of a firming in the stance of monetary policy."
\end{abstract}

The estimated monetary shock is contractionary (but not large) on the day that statement was released, May 18, 1999 (recall that we define a positive monetary shock as a contractionary monetary shock or a tightening of monetary policy).

Figure 6 plots the estimated monetary shock on the final day of each scheduled FOMC meeting since May 1999. A few notable dates are highlighted in the chart. These are:

\footnotetext{
${ }^{11}$ The ratio of two variances follows an F-distribution. The ratio of the variance of the monetary or risk shock in the post-ZLB period to the same shock in the pre-Lehman period is greater than 1 with p-value equal to 0 . The ratio of the variances of the demand and supply shocks in the post-ZLB period to those in the pre-Lehman period are statistically greater than one with p-values 0.29 and 0.06 , respectively.
} 
1. December 2008: The zero lower bound (ZLB) is reached as the FOMC cuts the federal funds rate from a target level of 1 percent to a target range of 0 to 25 basis points.

2. March 2009: The FOMC announces an increase in the size of the large scale asset purchase program or QE1

3. September 2010: QE2 hinted at (by adding the phrase "provide additional accommodation if needed" to the post-meeting statement); QE2 announced at the subsequent FOMC meeting in November ${ }^{12}$

4. August 2011: Introduction of (date based) forward guidance in the form of an observation that economic conditions "...are likely to warrant exceptionally low levels for the federal funds rate at least through mid-2013"

5. September 2012: Forward guidance extended until mid-2015

6. May/June 2013: Tapering first hinted at: "The committee is prepared to increase or reduce the pace of its purchases to maintain appropriate policy accommodation..."

7. September 2013: Expected tapering did not start: “...the Committee decided to continue purchasing additional agency mortgage-backed securities at a pace of $\$ 40$ billion per month and longer-term Treasury securities at a pace of \$45 billion per month."

8. March 2015: Patient removed from statement, but Fed is clear that lift-off is not imminent: "The Committee anticipates that it will be appropriate to raise the target range for the federal funds rate when it has seen further improvement in the labor market and is reasonably confident that inflation will move back to its 2 percent objective over the medium term. This change in the forward guidance does not indicate that the Committee has decided on the timing of the initial increase in the target range."

\footnotetext{
${ }^{12}$ Note that Chairman Bernanke had also hinted at launching an additional large scale asset purchase program in his remarks at the Jackson Hole conference on August 27.
} 
Table 7 shows the variances of the estimated monetary shock on FOMC statement release days and ordinary days during the pre-Lehman and post-ZLB subperiods. Recall that by construction the variance of the monetary shock over the entire 1999-2015 period is one. And in table 6 we report that the variance is 0.72 in the pre-Lehman period and 1.08 in the post-ZLB period. By analyzing shocks on statement days separately from non-statement days, we find that the variance of the shock is slightly higher on statement days than non-statement days during the pre-Lehman period, but this increase is not statistically significant. However in the post-ZLB period, the estimated monetary shock is more than twice as volatile on statement days than on non-statement days. ${ }^{13}$

\section{[6.2] Effect of the statement on the size on monetary shocks}

So we observe two facts about FOMC statements and the monetary shock on the days the statements are released. First, the statements have been getting longer and more complex. Second, monetary shocks on FOMC statement days are getting bigger. So one question is how are these two related, are longer and more complex statements increasing the amount of information passed in each statement and leading to a larger monetary shock?

But of course there is an empirical problem here. We want to say that as the information content of statements has increased, that has led to larger monetary shocks (i.e. more bang for the statement buck). But the causality could run both ways. It could be that a longer and more detailed statement leads to a bigger impact, but it also could be that on a big announcement day (like announcing a new forward guidance, or a new QE program) the committee puts out a longer and more detailed statement.

One solution to this empirical problem is to turn back to the pre-ZLB period, and look at the statements from 1999 to 2008 , when there is a change (or no change) in the fed funds rate announced in each statement. We run a simple multivariate regression and regress the size of the monetary policy shock on the day the FOMC issues a statement on the change in the

\footnotetext{
${ }^{13}$ The ratio of the variance of the monetary shock on statement days to that on ordinary days in the pre-Lehman period is greater than 1 with $p$-value equal to 0.11 . The ratio of the variance of the monetary shock on statement days to that on ordinary days in the post-ZLB period is greater than 1 with $p$-value equal to 0 .
} 
federal funds rate and some proxy for the information content of the statement. This is a simple way of addressing the question, does the information content of the statement have an effect on the size of the monetary shock associated with a decision to either change or leave unaltered the federal funds rate after controlling for the actual monetary actions announced in the statement?

In Table 8 we present the results from the following regression:

$$
M_{t}=\alpha * \text { Surprise }_{t}+\beta * \text { Statement }_{t}+\gamma * \text { Statement }_{t} * \text { Surprise }_{t}+\epsilon_{t}
$$

where $M_{t}$ is the value of the monetary shock estimated from the sign restrictions VAR on the at the end of the day the statement was released and the rate implied by the nearby federal funds futures contract the day before, and Statement $t_{t}$ is some characteristic of the FOMC statement from that meeting (either the word count or the Flesch-Kincaid Grade Level), and $\epsilon_{t}$ is an error term.

The policy surprise has a positive and significant effect on the size of the monetary shock, as would be expected. A change in the Fed Funds rate above that which was expected is associated with a positive (contractionary) monetary policy shock. The point estimate of the coefficient shows that a policy surprise of 10 basis points leads to a contractionary monetary policy shock of 0.27 (recall from the first column of the impact matrix in table 3 , a monetary shock $M=1$ leads to a 1.9p.p. increase in the 10 year real interest rate, a 1.5p.p. decrease in the expected inflation rate, a 0.1 percent increase in the nominal exchange rate, a 0.63 percent decline in the S\&P 500, and a 2.3 percent increase in the VIX).

The statement variable on its own usually doesn't have a significant effect, but the interaction between the Fed action and the statement variable has a significant effect. For instance, the results in the third column of Table 8 say that every increase in the word count of the statement raises the effect of the same surprise change in the fed funds rate on the magnitude of the resulting monetary shock by 0.04 , every increase of 1 in the grade level increases the effect of the same federal funds rate change on the resulting monetary shock by 1.12 . 
The interaction term between the policy surprise and the statement characteristic variable is positive and significant, implying that as the statement gets longer or is written at a higher level, the monetary policy shock associated with a given policy change is larger. This suggests that longer and more complex statements that convey more information are able to deliver a larger monetary shock, and thus help the Fed move markets in their intended direction. ${ }^{14}$

Earlier we reported that the average statement from the post-1999 Greenspan Fed was 217 words long and the average statement from the pre-ZLB Bernanke Fed was 246 words long. The regression results imply that because the Bernanke statements were longer, the 10 basis point policy surprise from the Bernanke Fed would have led to a contractionary monetary policy shock that was larger by 0.1 .

One needs to exercise caution before extrapolating these regression results from pre-ZLB statements to the ZLB era, and in the next section we will discuss some ways this analysis can be extended to the ZLB period. But using a simple back of the envelope calculation and extrapolating these regression results to the ZLB period; the statements in the post-ZLB Bernanke Fed were on average 280 words longer than the statements from the pre-ZLB Bernanke Fed. The 10 basis point policy surprise from the post-ZLB Bernanke Fed would have led to a contractionary monetary policy shock that was larger by 1 standard deviation. In addition the grade level of the post-ZLB Bernanke Fed statements were on average 3 grade levels higher than those of the pre-ZLB Bernanke Fed. The 10 basis point policy surprise from the post-ZLB Bernanke Fed would have led to a contractionary monetary policy shock that was larger by 0.3 standard deviations.

\section{[7] Conclusions}

As the FOMC has had to deal with the greatest financial crisis since the Great Depression and exhausted conventional monetary options, unconventional monetary policy has played a

\footnotetext{
${ }^{14}$ Of course, word length and grade level are not perfect proxies for the information content of the statement, and one case certainly find examples of where increased wordiness or complexity are meant to obfuscate, not inform. But when examining the trend in FOMC statements over the last 20 years, the trend is towards longer and more technically complex statements that covey greater information about the Fed's outlook for the economy and expected future policy actions.
} 
greater role, and within the class of unconventional monetary policies, forward guidance - that is, communication about the likely future course of policy conditional of economic developments - has taken on greater importance. In this paper we have examined just one dimension of the FOMC's communications - the post meeting statement - and documented how it has evolved over time. We have sought to characterize some of the linguistic features of the statement that may have made it easier or more difficult to understand, and then shown how these characteristics correlate with estimates of monetary policy shocks.

While this analysis certainly suggests that the increased length and complexity of the statement during the ZLB period has been responsible for statements having such a large impact, the regression analysis performed in the last section relied on pre-ZLB observations, where the primary policy instrument was a change in the fed funds rate. To formally extend such analysis to the ZLB period one would need to quantify the effect of unconventional policy announcements, like the announcement of a new quantitative easing program. One possibility is to consider changes in something like changes in Eurodollar rates, but this is left as a direction for further research.

Of course the post meeting statement is just one of the ways the FOMC communicates with the public. It has always issued minutes after its meetings. Through 2004 the minutes were released two days after the subsequent meeting, which limited their usefulness in conveying the thinking behind the policy decision made at the meeting to which they referred. In December 2004 the decision was made to bring forward the release of the minutes and they now appear three weeks after the meeting to which they refer, providing additional insights into the thinking behind policy decisions. Two other major communications innovations have occurred in recent years. Following the long standing practices of other major central banks, the chairman now holds a press conference four times a year. Second the members of the Board of Governors and the individual Reserve Bank Presidents now release their economic forecasts four times a year as part of a regular Survey of Economic Projections. Previously these forecasts had only been reported twice a year as part of the regular monetary policy report to 
Congress (previously known as the Humphrey Hawkins testimony). And finally all of the Governors and Reserve Bank Presidents give regular speeches and interviews.

A more comprehensive analysis of FOMC communications would examine how information about monetary policy communicated through these channels interacts with measures of policy shocks. That is left for future work.

We briefly compared some of the characteristics of the FOMc's post-meeting statement with the press release issued by the Bank of Canada. It would be interesting to follow up with a broader comparison with more central banks in the English speaking world to see how the complexity of the communications of the different central banks evolved in the post-crisis period. ${ }^{15}$ We could also replicate our econometric analys for these countries, a project that we are currently engaged in.

\footnotetext{
${ }^{15}$ We are not sure how we would extend the exercise to central banks in non English speaking countries as we do not have access to the relevant text analysis software.
} 


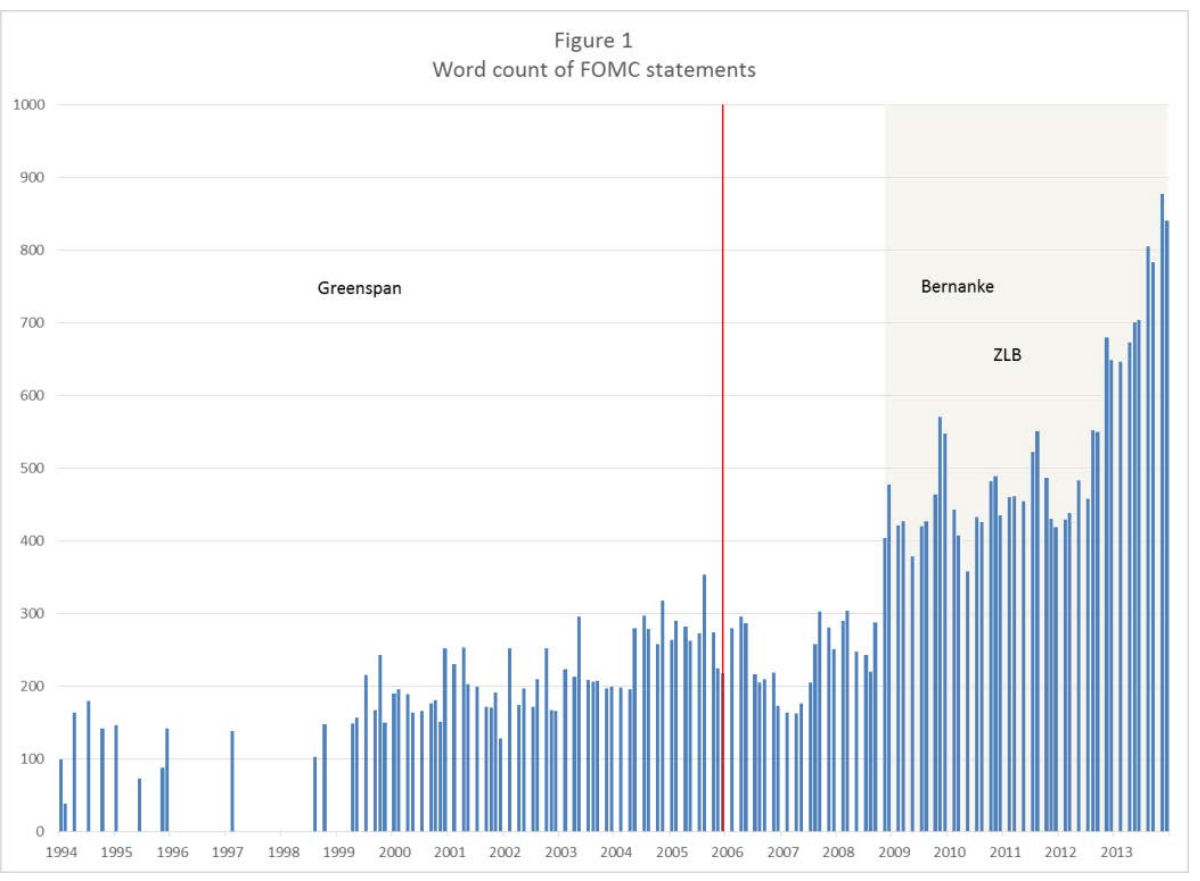

Notes to Figure 1: Source: Authors calculations. 


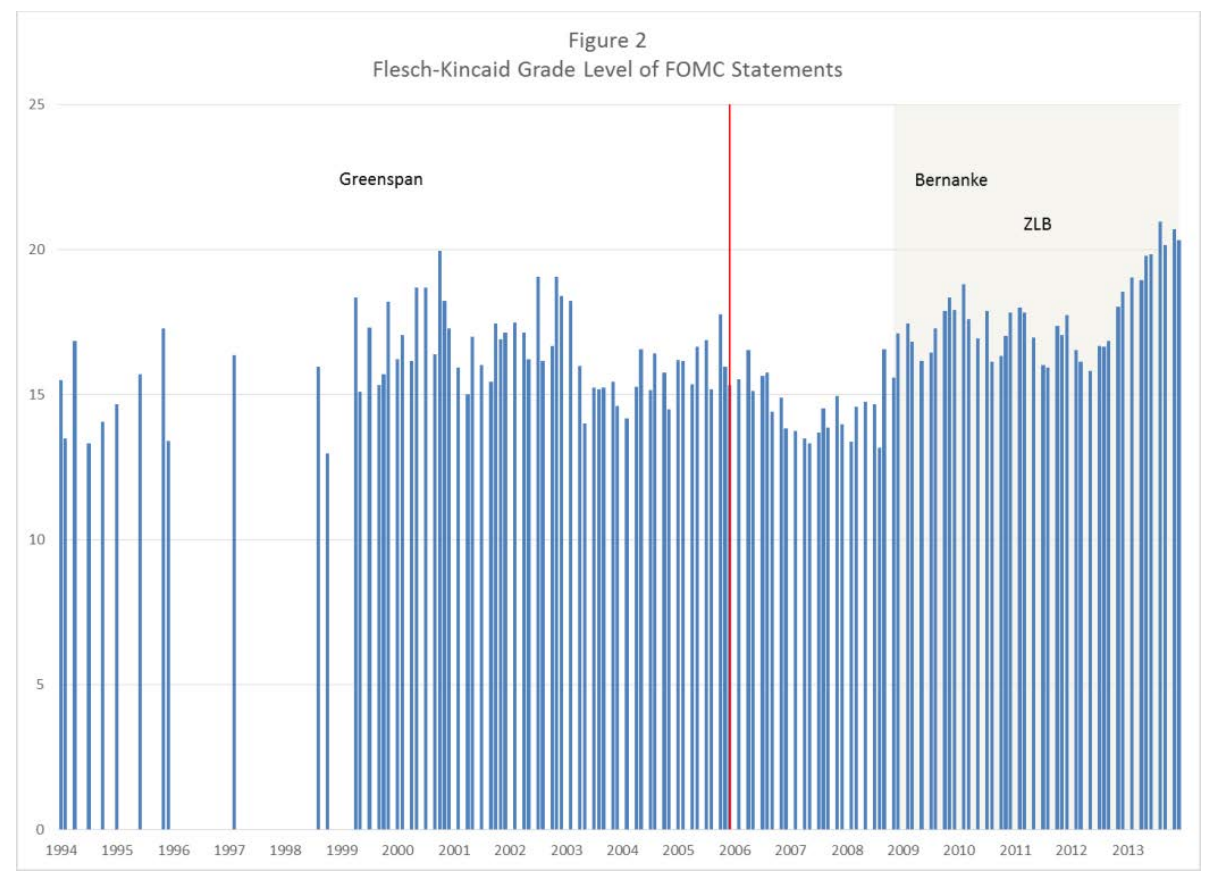

Notes to Figure 2: Source: Authors calculations. 


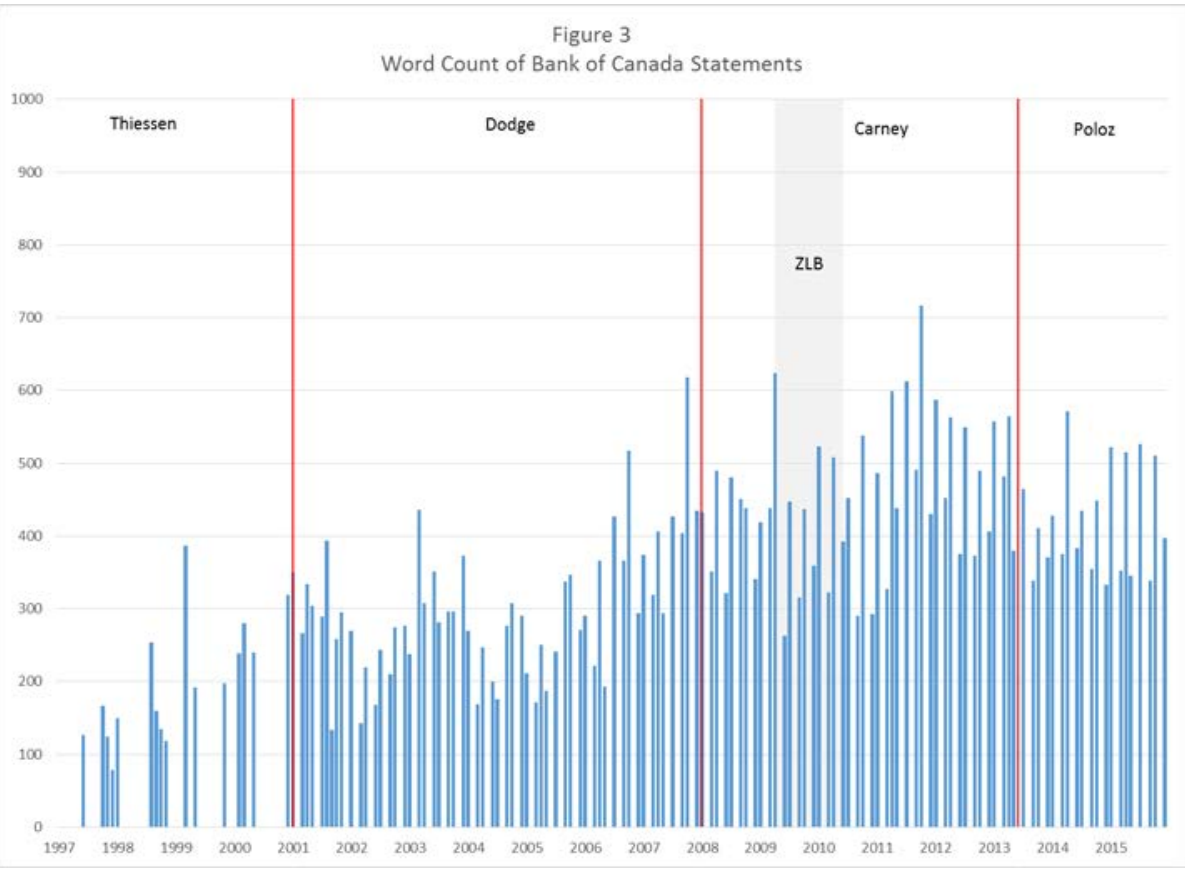

Notes to Figure 3: Source: Authors calculations. 


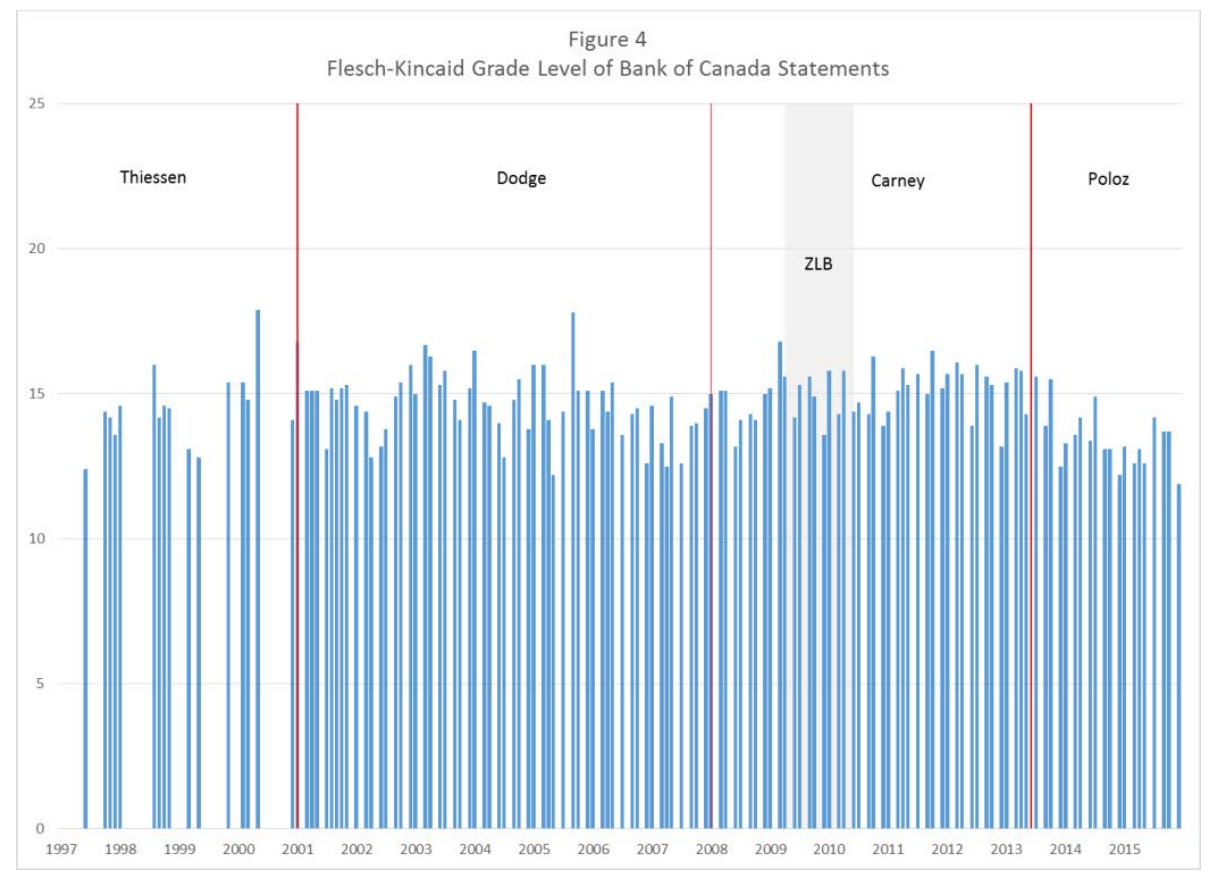

Notes to Figure 4: Source: Authors calculations. 


\section{Figure 5}

Time series of shocks estimated from Sign Restrictions VAR
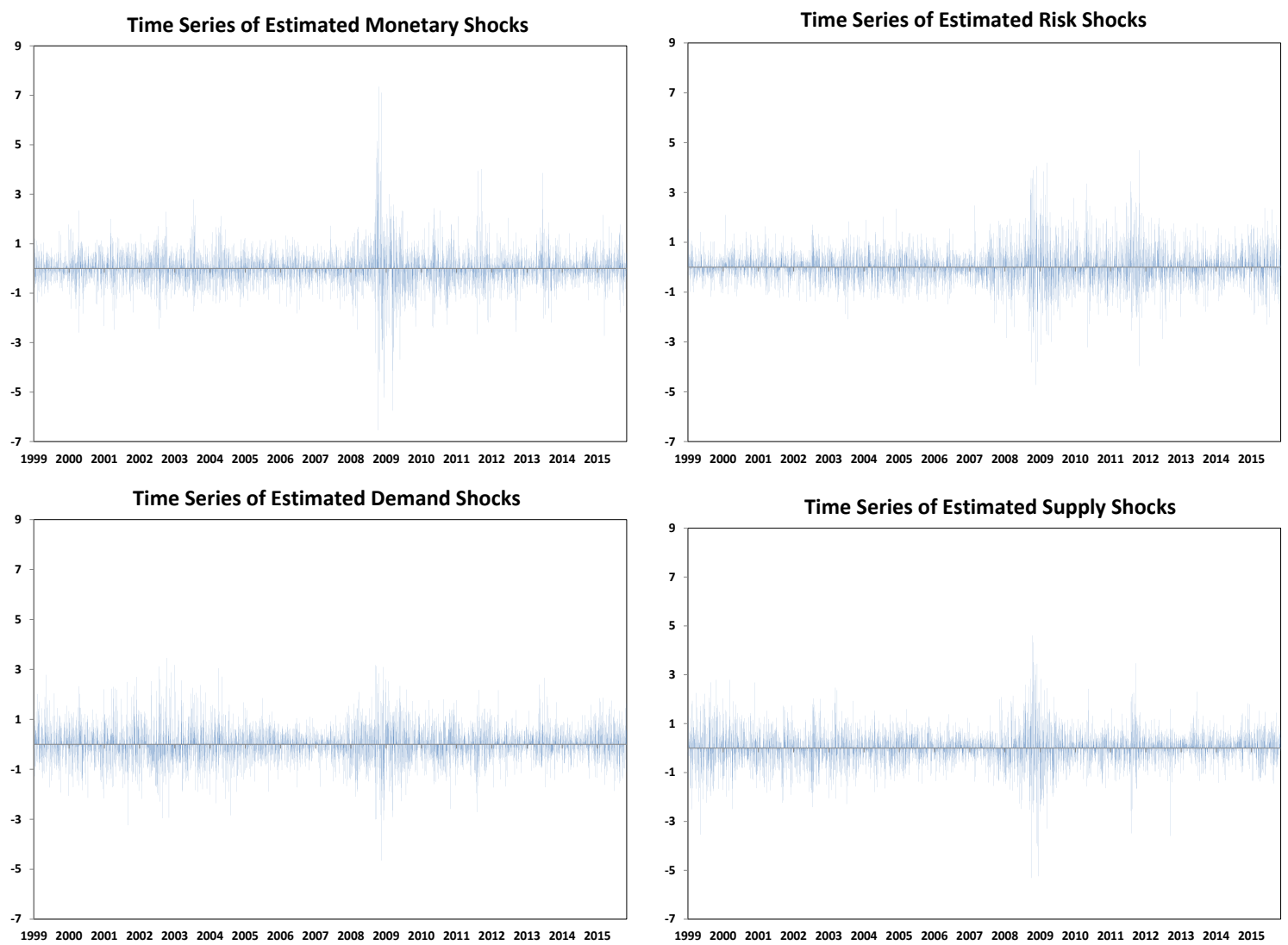

Notes to Figure 5: Source: Authors calculations. 
Figure 6

Monetary Shocks on FOMC Statement Release Days

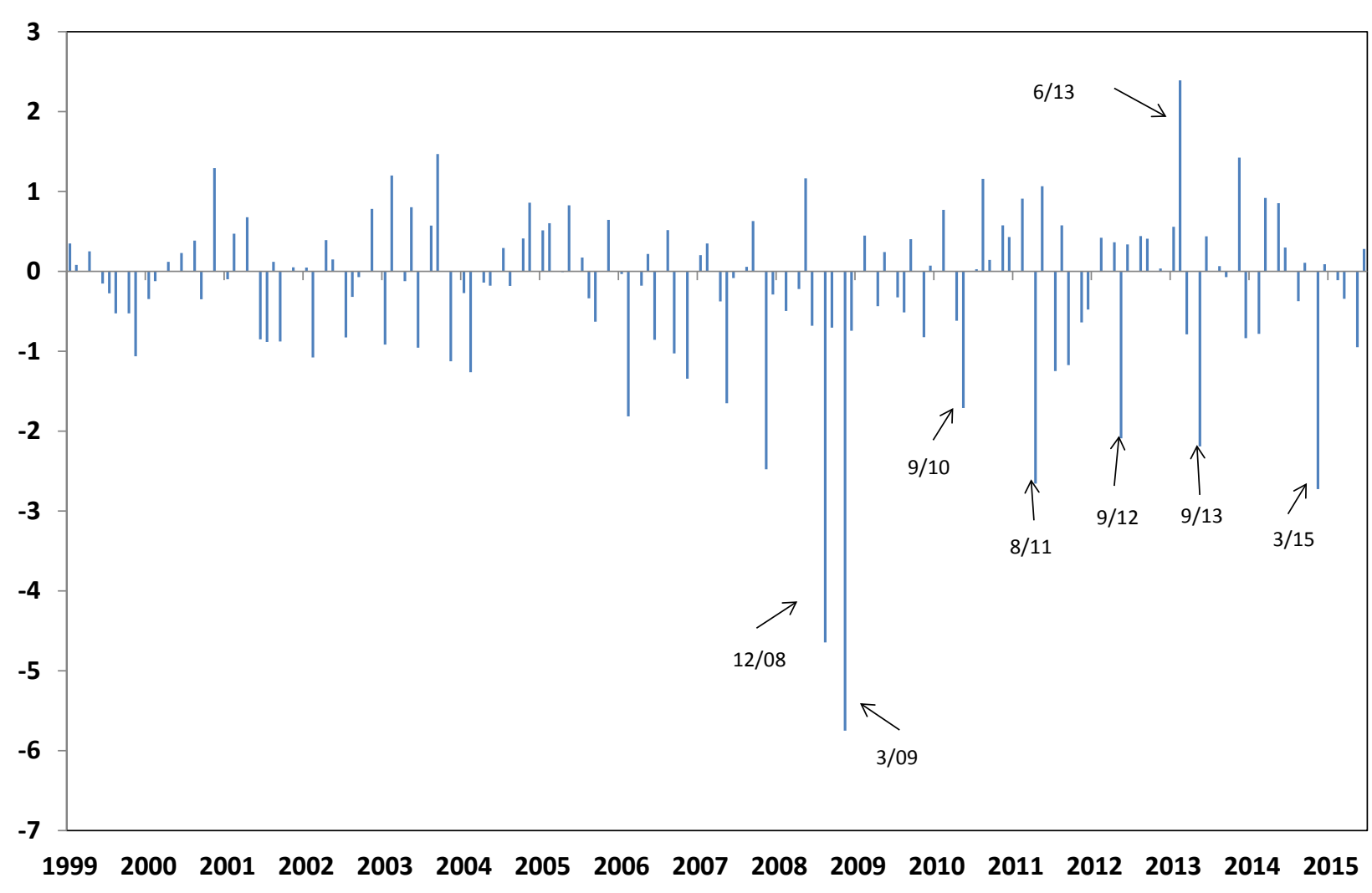

Notes to Figure 6: Source: Authors calculations. 
Table 1: Descriptive Statistics of the FOMC Statement

\begin{tabular}{|l|c|c|}
\hline & Word Count & Flesch-Kincaid grade level \\
\hline Greenspan (pre May 1999) & 122 & 15.0 \\
\hline Greenspan (post May 1999) & 217 & 16.5 \\
\hline Bernanke (pre ZLB) & 246 & 14.7 \\
\hline Bernanke (ZLB) & 529 & 17.7 \\
\hline
\end{tabular}

Notes to Table 1: Source: Authors calculations. 
Table 2: Differences in the statistics describing FOMC statements

\begin{tabular}{|l|l|l|l|l|}
\hline & $\begin{array}{l}\text { Greenspan } \\
\text { (pre May } \\
\text { 1999) }\end{array}$ & $\begin{array}{l}\text { Greenspan } \\
\text { (post May } \\
\text { 1999) }\end{array}$ & $\begin{array}{l}\text { Bernanke } \\
\text { (pre ZLB) }\end{array}$ & $\begin{array}{l}\text { Bernanke } \\
\text { (ZLB) }\end{array}$ \\
\hline $\begin{array}{l}\text { Greenspan } \\
\text { (pre May } \\
\text { 1999) }\end{array}$ & $95 * * *$ & $124 * * *$ & $407^{* * *}$ \\
\hline $\begin{array}{l}\text { Greenspan } \\
\text { (post May } \\
\text { 1999) }\end{array}$ & $-1.5^{* * *}$ & $29 * *$ & $312^{* * *}$ \\
\hline $\begin{array}{l}\text { Bernanke } \\
\text { (pre ZLB) }\end{array}$ & 0.3 & $1.9 * * *$ & $282^{* * *}$ \\
\hline $\begin{array}{l}\text { Bernanke } \\
\text { (ZLB) }\end{array}$ & $-2.7^{* * *}$ & $-1.2 * * *$ & $-3.1 * * *$ & \\
\hline
\end{tabular}

Notes to Table 2: Source: Authors calculations. Numbers in cells above the diagonal are the difference in mean word count between the period indicated in the column and the period indicated in the row. For example, the average post FOMC meeting statement issued during the early part of Chairman Greenspan's tenure was 407 words shorter than the average post FOMC meeting statement issued during Chairman Bernanke's tenure after December 2008 (the ZLB period). Numbers in cells below the diagonal are the mean difference in Flesch-Kincaid grade level readability. For example, the readability of the average post FOMC meeting statement issued during the ZLB period during Chairman Bernanke's tenure was 2.7 grade levels above the grade level readability of the average post FOMC meeting statement issued during Chairman Greenspan's tenure prior to May 1999 (calculated as $15-17.7=-2.7$ ). ${ }^{* * *}$ denotes significance at the 1 percent level; $* *$ denotes significance at the 5 percent level; ${ }^{*}$ denotes significance at the 1 percent level. 
Table 3: Descriptive statistics of the Bank of Canada policy statement

\begin{tabular}{|l|c|c|}
\hline & Word Count & Flesch-Kincaid grade level \\
\hline Thiessen & 207 & 14.6 \\
\hline Dodge & 298 & 14.6 \\
\hline Carney & 451 & 15.1 \\
\hline Carney (ex ZLB) & 461 & 15.1 \\
\hline Carney (ZLB) & 420 & 15.0 \\
\hline Poloz & 422 & 13.5 \\
\hline
\end{tabular}

Notes to Table 3: Source: Authors calculations. Statistics for Poloz are through December 2015 only. 
Table 4: Differences in the statistics describing Bank of Canada policy statements

\begin{tabular}{|c|c|c|c|c|c|c|}
\hline & Thiessen & Dodge & Carney & $\begin{array}{l}\text { Carney (ex } \\
\text { ZLB) }\end{array}$ & $\begin{array}{l}\text { Carney } \\
\text { (ZLB) }\end{array}$ & Poloz \\
\hline Thiessen & & $91 * * *$ & $244 * * *$ & $254 * * *$ & $213^{* * *}$ & $215^{* * *}$ \\
\hline Dodge & 0.0 & & $153^{* * *}$ & $163^{* * *}$ & $122^{* * *}$ & $124 * * *$ \\
\hline Carney & -0.5 & $-0.5^{* *}$ & & 10 & -31 & -29 \\
\hline $\begin{array}{l}\text { Carney (ex } \\
\text { ZLB) }\end{array}$ & -0.5 & $-0.5 * *$ & 0.0 & & -41 & -39 \\
\hline $\begin{array}{l}\text { Carney } \\
\text { (ZLB) }\end{array}$ & -0.4 & -0.4 & 09.1 & 0.1 & & 2 \\
\hline Poloz & $1.1 * * *$ & $1.1^{* * *}$ & $1.6 * * *$ & $1.6 * * *$ & $1.5^{* * *}$ & \\
\hline
\end{tabular}

Notes to Table 4: Source: Authors calculations. Numbers in cells above the diagonal are the difference in mean word count between the period indicated in the column and the period indicated in the row. For example, the average policy statement issued during the entirety of Governor Carney's tenure was 244 words longer than the average policy statement issued during Governor Thiessen's tenure. Numbers in cells below the diagonal are the mean difference in Flesch-Kincaid grade level readability between the period indicated in the column and the period indicated in the row. For example, the readability of the average policy statement issued during the ZLB period under Governor Carney was 0.4 grade levels above the grade level readability of the average policy statement issued during Governor Thiessen's tenure. ${ }^{* * *}$ denotes significance at the 1 percent level; ${ }^{* *}$ denotes significance at the 5 percent level; * denotes significance at the 1 percent level. 
Table 5

\begin{tabular}{|c|c|c|c|c|c|}
\hline \multicolumn{6}{|c|}{ Sign restrictions used to identify shocks - Sign restrictions in the matrix $S$} \\
\hline & $\begin{array}{c}\text { Monetary shock } \\
\text { "M" }\end{array}$ & $\begin{array}{c}\text { Risk shock } \\
\text { " } \sigma \text { " }\end{array}$ & $\begin{array}{c}\text { Demand shock } \\
\text { "D" }\end{array}$ & $\begin{array}{c}\text { Supply shock } \\
\text { "Sup" }\end{array}$ & $\begin{array}{c}\text { Measurement } \\
\text { error }\end{array}$ \\
\hline $\begin{array}{l}\text { 10-year TIPS } \\
\text { interest rate (R) }\end{array}$ & + & - & + & + & \\
\hline $\begin{array}{l}\text { 10-year expected } \\
\text { inflation rate (Ex) }\end{array}$ & - & & + & - & \\
\hline $\begin{array}{l}\text { Nominal effective } \\
\text { exchange rate } \\
\text { (FX) }\end{array}$ & + & + & + & + & \\
\hline S\&P 500 (SP) & - & - & & + & \\
\hline VIX (VIX) & & + & & & \\
\hline \multicolumn{6}{|c|}{ Average of 1000 estimated $S$ matrices - Average Impact matrix } \\
\hline & $\begin{array}{c}\text { Monetary shock } \\
\text { "M" }\end{array}$ & $\begin{array}{c}\text { Risk shock } \\
\text { " } \sigma \text { " }\end{array}$ & $\begin{array}{c}\text { Demand shock } \\
\text { "D" }\end{array}$ & $\begin{array}{l}\text { Supply shock } \\
\text { "Sup" }\end{array}$ & $\begin{array}{c}\text { Measurement } \\
\text { error }\end{array}$ \\
\hline $\begin{array}{l}\text { 10-year TIPS } \\
\text { interest rate (R) }\end{array}$ & 1.89 & -2.06 & 1.75 & 1.51 & 0.03 \\
\hline $\begin{array}{l}\text { 10-year expected } \\
\text { inflation rate (Ex) }\end{array}$ & -1.45 & -0.44 & 1.92 & -1.49 & 0.07 \\
\hline $\begin{array}{l}\text { Nominal effective } \\
\text { exchange rate } \\
\text { (FX) }\end{array}$ & 0.10 & 0.15 & 0.10 & 0.10 & 0.00 \\
\hline S\&P 500 (SP) & -0.63 & -0.51 & 0.41 & 0.44 & 0.02 \\
\hline VIX (VIX) & 2.27 & 2.66 & -1.61 & -1.54 & -0.13 \\
\hline
\end{tabular}

Notes to Table 5: A "+" sign indicates that we are restricting our search to $S$ matrices where that particular element is positive. A "-" sign indicates that the particular element must be negative. No sign indicates that the entry in the $S$ matrix can have any sign. 
Table 6: Sample variances of the estimated shocks in the model

\begin{tabular}{|l|c|c|c|c|}
\hline & $\begin{array}{c}\text { Monetary shock } \\
\text { "M" }\end{array}$ & $\begin{array}{c}\text { Risk shock } \\
\text { " } \sigma \text { " }\end{array}$ & $\begin{array}{c}\text { Demand shock } \\
\text { "D" }\end{array}$ & $\begin{array}{c}\text { Supply shock } \\
\text { "Sup" }\end{array}$ \\
\hline Pre Lehman & 0.72 & 0.72 & 0.92 & 0.89 \\
\hline Post ZLB & 1.08 & 1.18 & 0.95 & 0.95 \\
\hline
\end{tabular}

Notes to Table 6: Source: Authors calculations. 
Table 7: Sample variance of the monetary shock on FOMC statement days and non-statement days

\begin{tabular}{|l|c|c|}
\hline & Statement day & Non-statement Day \\
\hline Pre Lehman & 0.86 & 0.71 \\
& $(75)$ & $(2340)$ \\
Post ZLB & 2.26 & 1.04 \\
& $(56)$ & $(1665)$ \\
\hline
\end{tabular}

Notes to Table 7: Source: Authors calculations. Number of observations in each category in parenthesis. 
Table 8: Results from a regression of the estimated monetary shock on the FOMC policy surprise and statement characteristics

\begin{tabular}{|c|c|c|c|c|c|c|}
\hline \multicolumn{7}{|c|}{ Dependent variable: Monetary Shock } \\
\hline \multirow[t]{2}{*}{ Value of Policy Rate Surprise } & $2.76^{* *}$ & $2.89 * *$ & -6.59 & $2.84^{* *}$ & -12.99 & $-38.27 * * *$ \\
\hline & $(1.14)$ & $(1.13)$ & (5.39) & $(1.15)$ & $(11.42)$ & $(14.39)$ \\
\hline \multirow[t]{2}{*}{ Word Count of Statement } & & $0.00 *$ & 0.00 & & & 0.00 \\
\hline & & $(0.00)$ & $(0.00)$ & & & $(0.00)$ \\
\hline \multirow[t]{2}{*}{ Surprise*Word Count } & & & $0.04 *$ & & & $0.05^{* *}$ \\
\hline & & & $(0.02)$ & & & $(0.02)$ \\
\hline \multirow[t]{2}{*}{ Flesch-Kincaid Grade Level } & & & & 0.07 & 0.04 & 0.00 \\
\hline & & & & $(0.06)$ & $(0.07)$ & $(0.07)$ \\
\hline \multirow[t]{2}{*}{ Surprise*Grade Level } & & & & & 1.01 & $1.74^{* *}$ \\
\hline & & & & & $(0.73)$ & $(0.74)$ \\
\hline $\mathrm{R}^{2}$ & 0.08 & 0.11 & 0.14 & 0.08 & 0.09 & 0.18 \\
\hline \# obs. & 78 & 78 & 78 & 78 & 78 & 78 \\
\hline \multirow[t]{2}{*}{ Time trend } & $-0.01 * *$ & -0.01 & -0.01 & $-0.01 * *$ & $-0.01 * *$ & -0.01 \\
\hline & $(0.00)$ & $(0.01)$ & $(0.01)$ & $(0.01)$ & $(0.01)$ & $(0.01)$ \\
\hline \multirow[t]{2}{*}{ Value of Policy Rate Surprise } & $3.13 * * *$ & $3.11 * * *$ & -5.46 & $3.14 * * *$ & -16.07 & $-37.62 * * *$ \\
\hline & $(1.13)$ & $(1.13)$ & $(5.44)$ & $(1.13)$ & $(11.20)$ & $(14.34)$ \\
\hline \multirow[t]{2}{*}{ Word Count of Statement } & & 0.00 & 0.00 & & & 0.00 \\
\hline & & $(0.00)$ & $(0.00)$ & & & $(0.00)$ \\
\hline \multirow[t]{2}{*}{ Surprise*Word Count } & & & 0.03 & & & $0.05 * *$ \\
\hline & & & $(0.02)$ & & & $(0.02)$ \\
\hline \multirow[t]{2}{*}{ Flesch-Kincaid Grade Level } & & & & -0.03 & -0.07 & -0.06 \\
\hline & & & & $(0.08)$ & $(0.08)$ & $(0.08)$ \\
\hline \multirow[t]{2}{*}{ Surprise*Grade Level } & & & & & $1.23^{*}$ & $1.79 * *$ \\
\hline & & & & & $(0.71)$ & $(0.74)$ \\
\hline $\mathrm{R}^{2}$ & 0.13 & 0.12 & 0.14 & 0.12 & 0.14 & 0.19 \\
\hline \# obs. & 78 & 78 & 78 & 78 & 78 & 78 \\
\hline
\end{tabular}

Notes to Table 8: Sample period: 1999-2008. Dependent variable: monetary policy shock as estimated using sign restrictions in a five variable VAR. "Surprise" denotes the surprise component monetary policy shock as estimated by the difference between the value of the federal funds rate at the end of the day of an FOMC meeting and the rate implied by the nearby federal funds futures contract the day before the FOMC meeting. Standard errors in parentheses. $* * * / * * / *$ denote significance at the $1 / 5 / 10$ percent level\} 


\section{References}

Antolín-Díaz, Juan and Juan F. Rubio-Ramírez, 2015. "Understanding the Turbulence in Financial Markets of August 2015: Can modern macroeconometrics help?" Manuscript.

Amato, Jeffrey D., Stephen Morris and Hyun Song Shin, 2002. "Communication and monetary policy." Oxford Review of Economic Policy, 18, 495-503.

Armesto, Michelle T., Rubén Hernández-Murillo, Michael T. Owyang and Jeremy Piger, 2009. "Measuring the information content of the Beige Book: A mixed data sampling approach." Journal of Money, Credit and Banking, volume 41, number 1, 35-55.

Balke, Nathan S., and D'Ann Petersen, 2002. "How well does the Beige Book reflect economic activity?" Journal of Money, Credit and Banking, 34, 114-136.

Berger, Helge, Michael Ehrmann and Marcel Fratzscher, 2011. "Monetary policy in the media." Journal of Money, Credit and Banking, 43, 689-709.

Bligh, Michelle C., and Gregory D. Hess, 2007. "The power of leading subtly: Alan Greenspan, rhetorical leadership, and monetary policy." The Leadership Quarterly, 18, 87-104.

Blinder, Alan S., Charles Goodhart, Philipp Hildebrand, David Lipton and Charles Wyplosz, 2001. How Do Central Banks Talk? Geneva Reports on the World Economy 3. London: Center for Economic Policy Research.

Blinder, Alan S., Michael Ehrmann, Marcel Fratzscher, Jakob De Haan and David-Jan Jansen, 2008. "Central bank communication and monetary policy: A survey of theory and evidence." Journal of Economic Literature, 46, 910-945.

Brunner, Karl, 1981. "The art of central banking." University of Rochester Center for Research in Government Policy and Business Working paper GPB 81-6.

Dale, Spencer, Athanasios Orphanides and Pär Österholm, 2011. “Imperfect central bank communication: Information versus distraction." International Journal of Central Banking, volume 7 , number 2, 3-39. 
Ehrmann, Michael and Marcel Fratzscher, 2005. "How should central banks communicate?" European Central Bank Working Paper Series No. 557.

----- and -----, 2007. “Communication by central bank committee members: Different strategies, same effectiveness?" Journal of Money, Credit and Banking, volume 39, number 2-3, 509-541.

----- and -----, 2013. “Dispersed communication by central bank committees and the predictability of monetary policy decisions." Public Choice, 157, 223-244.

Flesch, Rudolph, 1948. "A new readability yardstick." Journal of Applied Psychology, 32, 221233.

Friedman, Benjamin M., 2003. "The use and meaning of words in central banking: inflation targeting, credibility and transparency." In Paul Mizen Essays in honour of Charles Goodhart. Volume 1. Central banking, monetary theory and practice. Cheltenham, U.K. and Northampton, MA: Elgar.

Fulmer, Michael, 2013. "A text analytics analysis of the federal Reserve Beige Book corpus." PhD thesis, Department of Economics, Southern Methodist University.

Goodfriend, Marvin, 1986. "Monetary mystique: Secrecy and central banking." Journal of Monetary Economics, 17, 63-92.

Graesser, Arthur C., Danielle S. McNamara, Max M. Louwerse and Zhiqiang Cai, 2004. “CohMetrix: Analysis of text on cohesion and language." Behavior Research Methods, Instruments and Computers, 36, 193-202.

Graesser, Arthur C., Danielle S. McNamara and Jonna Kulikowich, 2011. “Coh-Metrix: Providing Multilevel Analyses of Text Characteristics." Education Researcher, 40, 223-234.

Guthrie, Graeme, and Julian Wright, 2000. “Open mouth operations." Journal of Monetary Economics, 46, 489-516.

Kincaid, J. Peter, Robert P. Fishburne Jr., Richard L. Rogers, and Brad S. Chissom, 1975. "Derivation of new readability formulas (Automated Readability Index, Fog Count and Flesch 
Reading Ease Formula) for Navy enlisted personnel." Research Branch Report 8-75, Millington, TN: Naval Technical Training, U. S. Naval Air Station, Memphis, TN.

Myatt, David P., and Chris Wallace, 2014. "Central bank communication design in a LucasPhelps economy." Journal of Monetary Economics, 63, 64-79.

Poloz, Stephen S., 2015. "Prudent preparation: The evolution of unconventional monetary policies." Remarks at the Empire Club of Canada, December 8, 2015.

Wynne, Mark A., 2013. "A Short History of FOMC Communication." Federal Reserve Bank of Dallas Economic Letter, volume 8, number 8.

Yellen, Janet L., 2012. "Revolution and evolution in central bank communications." Remarks at Haas School of Business, University of California, Berkeley, November 13, 2012. 